This is a pre-copyedited, author-produced PDF of an article accepted for publication in Parliamentary Affairs following peer review. The version of record Peace T (2013) All I'm asking, is for a little Respect: assessing the performance of Britain's most successful radical left party, Parliamentary Affairs, 66 (2), pp. 405-424 is available online at:

http://pa.oxfordjournals.org/content/66/2/405 


\title{
All I'm asking, is for a little Respect: assessing the performance of Britain's most successful radical left party
}

\author{
BY TIMOTHY PEACE ${ }^{1}$
}

\begin{abstract}
This article offers an overview of the genesis, development and decline of the Respect Party, a rare example of a radical left party which has achieved some degree of success in the UK. It analyses the party's electoral fortunes and the reasons for its inability to expand on its early breakthroughs in East London and Birmingham. Respect received much of its support from Muslim voters, although the mere presence of Muslims in a given area was not enough for Respect candidates to get elected. Indeed, despite criticism of the party for courting only Muslims, it did not aim to draw its support from these voters alone. Moreover, its reliance on young people and investment in local campaigning on specific political issues was often in opposition to the traditional ethnic politics which have characterised the electoral process in some areas.
\end{abstract}

When the British public awoke on the morning of Friday $6^{\text {th }}$ May 2005 most would have been unsurprised to discover that the Labour Party had clung on to power but with a reduced majority, as had been widely predicted. What few had expected was that one of those lost seats would have gone to the former Labour MP George Galloway and his Respect party (hereafter Respect). This was the first time a party to the left of Labour had won a seat in parliament since 1951. Respect also managed to elect a number of local councillors between 2004 and 2010 and at one point was even the official opposition to Labour on the council of the London borough of Tower Hamlets. Despite these modest gains, it is perhaps unsurprising that this party has been rather neglected by scholars of politics. ${ }^{2}$ After all, one could justifiably argue that attention should not be devoted to 'single issue parties' that represent a mere protest vote amongst one particular community. This article endeavours to dispel some of the assumptions held about Respect and its supporters. It is also argued that despite its gradual decline since 2008, the emergence of the party constitutes an interesting experiment in local democracy. It mobilised a number of activists with no previous experience of party politics and its grassroots campaigns shook up the electoral landscape in a number of previously safe Labour heartlands. This coincided with a general increase in the representation of minor parties and independents in the UK. ${ }^{3}$ The article gives an overview of the formation and early development of Respect and analyses its electoral fortunes. It also charts its inexorable decline after the split from the Socialist Workers Party (SWP) in late 2007. Consideration is then given to how Respect was able to mobilise its supporters during elections and the reasons for its success, particularly amongst some Muslim communities in Britain.

\section{Founding and early electoral contests}

The origins of Respect are to be found in the British anti-war movement that developed from late 2001 onwards and culminated in the massive demonstrations against the invasion of Iraq on $15^{\text {th }}$ February 2003. The Stop the War Coalition (StWC) was officially set up on 21st September 2001, and the SWP, the largest radical left grouping in the UK, took a leading role. One of the novel aspects of the anti-war movement was the sizeable contribution of British Muslims and in particular 
the politicization of young Muslims with no previous experience of political activism. Salma Yaqoob became the leader of the StWC in Birmingham and she quickly emerged as an important figurehead for the movement. Eventually, the hitherto largely unknown Muslim Association of Britain (MAB) became an official partner of the StWC in the organisation of demonstrations where their placards became omnipresent. ${ }^{4}$ A number of rebel Labour MPs also associated themselves with the StWC including Katy Clark, Jeremy Corbyn, Tam Dalyell, George Galloway and Alice Mahon. Tony Benn, who had retired as an MP in 2001, was elected as the coalition's president. The electoral fallout for Labour after the invasion of Iraq became clear when it lost a series of council seats in local elections in Birmingham and Leicester in May 2003, both cities with a sizeable Muslim population. Labour lost control of Birmingham city council after 19 years in power and it was clear that Muslim voters had played a crucial role as 11 of the 39 seats lost by Labour were from the inner city wards with a large number of Muslim residents. Later that year, Labour also came second to the Liberal Democrats in a parliamentary contest when Sarah Teather won a byelection in the previously safe Labour seat of Brent East. Adverse reaction to the Iraq War was again cited as a major contributing factor. George Galloway had been suspended from holding office in the Labour party in May 2003 and was eventually expelled from the party in October 2003 after being found guilty of four of the five charges of bringing the party into disrepute. ${ }^{5} \mathrm{He}$ then announced that he would stand against Labour in the 2004 European elections and 'seek to unify the red, green, anti-war, Muslim and other social constituencies radicalised by the war, in a referendum on Tony Blair'. ${ }^{6}$

Discussions subsequently began about forming an electoral coalition as an anti-war alternative that would federate all those to the left of Labour. This new party would be, in effect, the successor to the Socialist Alliance electoral list which had presented itself at the 2001 general election earning 57,553 votes, a respectable figure considering the low expectations of British socialists. However, those spearheading the new party sought to capitalise on the success of the anti-war movement and did not want to restrict themselves to the usual suspects of the radical left. The two main instigators of the project, Salma Yaqoob and the political activist and writer George Monbiot, were also looking to reach out to other constituencies that had been galvanised by the campaign against the invasion of Iraq such as peace activists and faith groups, particularly Muslims. In November 2003, a series of public meetings was organised under the heading "British Politics at the Crossroads" and it was decided to go ahead with the idea of creating a new party. 'Respect - the unity coalition' was officially launched at a convention on $24^{\text {th }}$ January 2004 . The name was chosen as an acronym standing for Respect, Equality, Socialism, Peace, Environmentalism, Community, and Trade Unionism. A number of trade unionists were either closely involved in the project such as Linda Smith from the Fire Brigades Union (FBU) or were supportive of the party like Mark Serwotka of the Public and Commercial Services Union (PCS). After the disaffiliation of the National Union of Rail, Maritime and Transport Workers (RMT) from Labour in February 2004, some local branches subsequently voted to support Respect. In addition to the call for the end of the war and occupation in Iraq, the party's founding declaration called for an end to privatisation and the re-nationalisation of the railways. Nevertheless, it was unable to secure the full backing of any of the major unions despite being the only party calling for the repeal of 'Tory anti-union laws'. Attempts were made to create electoral pacts with the Green Party but these negotiations were also unsuccessful. The decision to then field candidates against the Greens led to the resignation of cofounder George Monbiot who argued that he could not 'continue to belong to a party which stands against the Greens in the European elections, particularly as this might endanger the seats of two of the best elected representatives in Britain: Caroline Lucas and Jean Lambert'?

The resignation of Monbiot was a blow but Respect activists had to focus their attention on the upcoming elections for the European parliament and the London Assembly to be held on June $10^{\text {th }} 2004$. Respect's manifesto for Europe boldly declared that: 
We will campaign for a different Europe, a Europe based on need not profit. A Europe which is a clear alternative to global capital, which opposes militarism and war, which is open to the needs of the countries of the South, which defends human rights and human dignity. A Europe of solidarity and hope. ${ }^{8}$

In an attempt to galvanise the anti-war vote, Respect leaders attempted to bill these elections as a referendum on Tony Blair. Both contests used proportional voting systems and confidence of achieving success was high. Galloway, who was standing for election to the European parliament in London, predicted that they might end up with as many as five MEPs. This was certainly an overoptimistic claim given the recent enlargement of the EU which meant that there was a reduction in the number of seats on offer in the UK, a factor that would particularly affect minor parties. Many of those who stood as candidates had been closely involved in the anti-war movement. Lindsey German (convenor of the StWC) was Respect's London mayoral candidate, Anas Altikriti (MAB) headed the European list in the Yorkshire and Humber region and John Rees (SWP) was at the top of the Respect list in the West Midlands. The party was widely derided by many in the media as just another single-issue party destined to disappear quickly from the electoral landscape. ${ }^{9}$ Nevertheless, Respect polled a quarter of a million votes in the European election and George Galloway received 91,175 votes in London, a total which in previous years may have guaranteed him a seat. ${ }^{10}$ The success of the United Kingdom Independence Party (UKIP) and the strong showing by the Green Party left Galloway and the other candidates empty handed however. It was a similar story in the London Assembly contest where Respect achieved $4.5 \%$ of the vote thereby also narrowly missing out on a seat. ${ }^{11}$ However, the breakdown of their performance showed that they had outperformed all other parties in the London boroughs of Tower Hamlets and Newham gaining more than $20 \%$ of the vote in these areas. This indicated that in parts of East London with large Muslim populations, Respect could genuinely compete with the other parties. After only half a year of existence, Respect activists could be sufficiently proud of these results which were a huge improvement on previous performances by the radical left. In the local council elections that were held at the same time, the party failed to elect any candidates. However, one month later Oliur Rahman, east London branch chairman of the PCS, produced Respect's first election victory at a council by-election in the St Dunstans and Stepney Green ward of Tower Hamlets with $31 \%$ of the vote. ${ }^{12}$ The party also performed reasonably well in parliamentary by-elections in Birmingham Hodge Hill (6.3\%) and Leicester South $(12.7 \%)$ which gave its activists increased impetus ahead of the forthcoming general election.

In December 2004, after winning a libel case against The Daily Telegraph, George Galloway announced that he would stand for election in Bethnal Green and Bow and challenge the Labour MP Oona King. Respect saw great potential for success in East London where three of the four sitting Labour MPs had voted in favour of the invasion of Iraq against the wishes of many of their constituents. ${ }^{13}$ The other Respect candidates in this area for the 2005 general election were Lindsey German (West Ham), Abdul Khaliq Mian (East Ham) and Oliur Rahman (Poplar and Canning Town). The campaign in Bethnal Green and Bow was one of the most acrimonious in recent history. King accused Galloway of sexual impropriety (allegations she was later forced to retract) and Respect supporters of antisemitism after she was pelted with eggs at a Jewish memorial service. When asked how he felt about standing against one of the few black MPs, Galloway retorted that King had 'voted to kill a lot of women in the last few years. Many of them had much darker skins than her. ${ }^{14}$ Galloway went to great lengths in order to secure victory and promised that if he won the seat he would step aside at the next election for a candidate of Bengali origin. Like other candidates before him, he made a trip to Bangladesh - where many residents of the constituency have family members - in order to drum up support. The 2005 general election saw Respect put forward 26 candidates in England and Wales. Nationwide, the party won on average $6.8 \%$ of the vote in the constituencies it contested and performed poorly in most areas with 17 of their candidates losing their deposit. However, in East London it was another story, where Galloway was elected by a margin of just 823 votes, overturning a Labour majority of over 10,000. His victory was one of the big stories of an election that saw minor parties make important gains. ${ }^{15}$ 
Most will remember Galloway's victory for the notorious post election interview with Jeremy Paxman who repeatedly questioned him on whether he was proud of unseating one of the few black women in parliament. ${ }^{16}$ The other Respect candidates in the East End also performed well, German and Mian both came second to Labour and Rahman was narrowly beaten into third place by the Conservatives. Salma Yaqoob finished second in the Birmingham Small Heath and Sparkbrook constituency with a credible $27.5 \%$ of the vote. By the end of the year, two Labour councillors and one Liberal Democrat had defected to Respect in the London borough of Newham.

2006 started with Galloway's participation in Celebrity Big Brother in an attempt to connect to a wider audience. This PR move backfired as many of his political speeches were censored by the producers and media attention focused on his impersonation of a cat and the abandonment of his constituents. ${ }^{17}$ It did not harm the appeal of the Respect Party though as in the local elections in May the borough of Tower Hamlets saw the party's most impressive success to date with 11 new councillors being elected, subsequently making it the official opposition to Labour. Respect put forward over 150 candidates nationwide and in Newham, the 3 existing Respect councillors retained their seats although the party was disappointed to not have increased their presence in the council chamber after receiving $26 \%$ of the vote throughout the borough. ${ }^{18}$ In Birmingham, Salma Yaqoob was elected as a local councillor with the party receiving a jaw-dropping $55 \%$ of the vote in the Sparkbrook ward, thereby becoming the first female Muslim councillor in the city. In local elections the following year, the party fielded 45 candidates but only added 3 councillors to their total (including a lone representative on Bolsover district council). The party had peaked and thus commenced a period of slow decline with Galloway suspended from the House of Commons for 18 days in July 2007 after the standards and privileges committee accused him of a lack of transparency regarding the financing of his charity, the Mariam Appeal. The resignation of a Respect councillor in Tower Hamlets triggered a by-election in August. Former Labour leader of the council Michael Keith attempted to win back the seat he had lost one year previously. However, to the surprise of many, Harun Miah managed to narrowly hold on to the seat for Respect. ${ }^{19}$ Despite this victory, petty squabbles developed into deep divisions concerning the functioning and nature of the party. This eventually led to a split within the fractious coalition.

\section{The split from the SWP and slow decline}

The SWP was a significant component of the 'unity coalition' and its activists had contributed massively to electoral campaigning. Two of its leading figures, Lindsey German and John Rees, were prominent leaders in Respect. Yet the relationship between the SWP and George Galloway was always strained. In late August 2007 he sent a letter to the national council pointing out the internal weaknesses of Respect, interpreted by many as a veiled criticism of the SWP. This developed into a heated argument between SWP leading lights and Galloway and led to internal tensions within the SWP itself which subsequently expelled two of its own members for failing to obey a leadership instruction to stop working as Galloway's parliamentary assistants. By the end of October, it became clear that the status quo could not continue and the SWP began to claim in their publications that there was 'witch hunt' inside Respect against socialists - a bizarre claim given the existence of other socialist factions. In a separate development, four Tower Hamlets councillors resigned the Respect whip on $29^{\text {th }}$ October 2007. This was due to disagreements between Abjol Miah, leader of the Respect group in Tower Hamlets, and Oliur Rahman. The councillors who resigned the whip were accompanied during their press conference by John Rees. ${ }^{20}$ By November 2007 then, the party had split into two rival factions. The first mainly consisted of those connected to the SWP and included the rebel councillors. The second faction, initially entitled 'Respect renewal', was led by Galloway and Yaqoob and included prominent personalities such as the national chair Linda Smith. ${ }^{21}$ The ensuing battle was characteristic of the faction fighting that has always plagued the radical left. Members of the Galloway faction changed the locks of the Respect 
national office, thereby barring access to SWP supporters. The party website, still controlled by members who were affiliated with the SWP, maintained that they were the real party and that Galloway had simply left. The culmination of this farce was the hosting of two separate Respect conferences on November $17^{\text {th }} 2007$ where each side claimed that its conference was the only legitimate meeting of the party faithful. ${ }^{22}$ The stalemate continued for another two months but the rules of the Electoral Commission meant that only one side could retain the Respect name for elections. As Nominating Officer, Linda Smith controlled the use of this name and so Galloway's faction eventually won the battle to be known as Respect. This was the most logical outcome as virtually all of the party's elected representatives and members of the national council had in any case already sided with Galloway.

Both Respect and the SWP breakaway faction - now renamed as The Left List, campaigned for the 2008 London Assembly election although Respect did not put forward a mayoral candidate. ${ }^{23}$ The Left List's candidate Lindsey German polled just 16,796 first preference and 35,057 second preference votes, a substantial decrease from when she was the Respect mayoral candidate in 2004. Respect was still in disarray and only put one constituency candidate forward for the London Assembly election, unsurprisingly in the City and East constituency. Hanif Abdulmuhit fared reasonably well with $15 \%$ of the vote, however he still trailed the Labour and Conservative candidates by a significant margin. The London-wide top-up results for Respect were poor, the $2.4 \%$ they managed was a long way off the $5 \%$ threshold needed to win a seat. The party continued to regroup over the rest of 2008 and the conflict in Gaza which erupted late in the year gave Respect activists a new cause to campaign on. During 2009, the party, and Galloway in particular, put most of its resources into organising and raising funds for the Viva Palestina aid convoy to help alleviate the humanitarian situation in Gaza. The first convoy which left Glasgow on $14^{\text {th }}$ February 2009 and arrived in Gaza just under one month later, was led by Kevin Ovenden who had been expelled from the SWP during the split in Respect. The party did not put forward candidates for the European elections of 2009, instead encouraging people to vote for either the Green party or the left-wing alliance No2EU. Two more aid convoys were organised before the end of a year which saw Galloway banned from Canada and by January 2010 he had also become persona non grata in Egypt. Looking towards the upcoming general election, Respect was targeting three seats. Galloway had announced that he would challenge fellow Scot Jim Fitzpatrick in the newly created Poplar and Limehouse constituency. Respect leader in Tower Hamlets council Abjol Miah was aiming to hold on to Galloway's seat in Bethnal Green and Bow and Salma Yaqoob, now leader of the party, was to contest Birmingham Hall Green. Council elections scheduled for the same day in Tower Hamlets and Newham meant that $6^{\text {th }}$ May 2010 would be a critical juncture for the party and its continued survival.

The Respect campaign started on a positive note when two Labour councillors in Tower Hamlets decided to defect to the party in March. The increasingly likely prospect of a hung parliament also meant that if the party were to elect two or three MPs, they could actually have some kind of influence in the House of Commons. Accordingly, Respect optimistically launched its 'manifesto for a hung parliament' on $26^{\text {th }}$ April in which it explained its three minimum conditions on which its MPs would consider supporting a government. Firstly, it called for a council house building programme to 'address the housing scandal across the country'. Its second demand, in keeping with its anti-war origins, was for the rapid withdrawal of British troops from 'illegal and pointless wars'. Finally, it called for a proportional voting system and the abolition of the appointed House of Lords. Responding to the expenses scandal, the party also claimed it would also push for the 'cleaning up of parliament'. Although it may have appeared rather presumptuous to dictate conditions to a prospective minority government, Respect needed to convince potential voters that it was a serious contender and that not only could it improve on the one MP from the last election but that its representatives could have an impact beyond their meagre numbers. This time around it would not be enough to rely on a protest vote from disaffected Labour supporters disillusioned with the decision to invade Iraq. Yaqoob's campaign was boosted when Lynne Jones, retiring Labour 
MP for Birmingham Selly Oak, decided to back her for the Hall Green seat over the Labour candidate Roger Godsiff. ${ }^{24}$ More good news followed when the Green party announced that it would not put forward a candidate against Yaqoob and also officially endorsed her candidacy. Respect had 10 candidates for the 2010 general election, mostly concentrated in London and the North West. Supporters were urged, however, to come to Birmingham to help canvass for Yaqoob who was also simultaneously campaigning to keep her seat on Birmingham city council. Unable to concentrate merely on the issue of Iraq, Galloway focused his campaign on discrediting sitting MP Fitzpatrick after an incident one year earlier when he decided to leave a Muslim marriage celebration because of gender segregation. The bridegroom involved in this incident even decided to stand as a Respect candidate at the Tower Hamlets council elections. Galloway also faced a strong challenge from the Conservative candidate Tim Archer whose quest to become the first Tory MP in the East End for over a century was helped by boundary changes that brought into the new Poplar and Limehouse seat the traditionally Conservative-supporting ward of Wapping and St Katherine's. In Bethnal Green and Bow, Abjol Miah concentrated his campaign on the issue of housing in a constituency where thousands are on the council house waiting list.

Both the general and local elections were unmitigated disasters for Respect. Not only did they fail to elect an MP, Galloway and Miah both finished back in third place achieving only $17 \%$ of the vote. To the surprise of many, Labour won both seats with relative ease. Godsiff also clinched Birmingham Hall Green although Yaqoob ran him even closer than in 2005 with a quarter of the votes polled and an $8 \%$ swing in her favour. Respect leaders put these results down to their core vote being swamped by an increase in turnout. Nationwide turnout was up by 4 percentage points but in the two East London constituencies they had hoped to win it had risen to $11 \mathrm{pp}$ (Bethnal Green) and 12pp (Poplar). They also attributed the increased support for Labour in these areas as a symptom of traditional Labour Party supporters returning to vote for the party out of fear of a prospective Conservative government. Respect was also not helped by both sets of elections being held on the same day. Nevertheless, the leadership could not hide behind the fact that nationwide it received only 33,251 votes, less than half the total in 2005 . Local council elections confirmed this downward trend. Before these elections Respect had eight councillors in Tower Hamlets, three in the London Borough of Newham and a further three on Birmingham City Council. In Tower Hamlets, Labour won 41 out of 51 seats, leaving Respect with just one councillor. In Newham there was a total whitewash for Labour just as there had been in Barking and Dagenham where the BNP lost its 12 councillors. In Birmingham, Salma Yaqoob easily retained her seat in the Sparkbrook ward where all 3 of its councillors were represented (only one seat in each of the city's wards was up for election). However, hopes had been high that she would become one of the first female Muslim MPs, instead this honour fell to three Labour candidates, including Rushanara Ali who had regained Respect's previous parliamentary seat.

\section{Respect results at major elections 2004-2010}

\section{Election}

2004 European

2004 London Assembly

2004 London Mayoral

2005 General

2008 London Assembly

2010 General

\section{Votes polled}

252,216

$82,301 / 87,533 *$

$61,731 / 63,294 * *$

68,094

$26,760 / 59,721 *$

33,251

\section{Share of votes in areas Seats won contested}

$\begin{array}{ll}1.7 \% & 0 \\ 4.6 \% / 4.57 \% & 0 \\ 3.2 \% / 3.3 \% & 0 \\ 6.8 \% & 1 \\ 1.1 \% / 2.4 \% & 0 \\ 6.8 \% & 0\end{array}$

* First figure refers to the constituency (First Past the Post) result, the second to the top-up (Additional Member System) result.

** First figure refers to 1 st preference votes, the second to 2 nd preference votes 


\section{Getting out the vote}

Since its inception, Respect has sought to position itself as a 'genuinely left' alternative to New Labour. Galloway himself has often described the party as the 'ghost of Labour's past' that would provide an alternative for left-wing voters who no longer felt represented by either Tony Blair or Gordon Brown. However, given the low levels of support for other parties to the left of Labour in Britain, Respect's electoral strategy has largely been based on targeting disenchanted Muslim voters dismayed by Labour and in particular by the decision to invade Iraq. ${ }^{25}$ Despite not having the resources of the mainstream parties, Respect's finances were quite healthy in the early years due to generous donations. The party spent more money on its 2005 general election campaign than established parties such as the Scottish National Party (SNP) and the Ulster Unionist Party (UUP). ${ }^{26}$ Finding donors was never a problem for the first three years even if the party had occasionally been forced to return impermissible donations. ${ }^{27}$ In the early phases of the coalition, local Respect branches in cities such as Sheffield, Preston, Brighton and Bristol, reflected the existing radical left and those interested in alternative politics. However, candidates for elections in these areas struggled to achieve success. The First Past the Post system makes it hard for smaller parties to win seats, although it can favour those parties whose support is geographically concentrated. Given the distribution of many Muslim communities in the UK, those involved in Respect knew that they could capitalise on the weakness of Labour in some of its former strongholds and that a significant number of Muslim voters would be willing to switch their allegiance. ${ }^{28}$ Election material initially projected Respect as 'the party for Muslims' and focused not only on the Iraq war but also antiterrorism legislation brought in by the government. ${ }^{29}$ However, at no point did it attempt to market itself as a 'Muslim political party' in the same vein as the failed Islamic Party of Britain (IPB) or the short lived Muslim Party in Birmingham. ${ }^{30}$ After the party's first election campaign in June 2004, it became apparent that the mere presence of Muslims in a given area was not enough for Respect candidates to receive support. In certain areas of high Muslim population (Yorkshire, Lancashire, Leicester) the party had little or no impact. The two areas where progress was made were Birmingham and East London, no doubt because the anti-war movement was already well established in these two areas and Respect activists had gained local credibility for their involvement in this movement. After 2005, Respect focused the majority of its efforts on these two areas with an essentially local campaigning strategy.

In order to understand this strategy, and also the difficulties Respect has faced in gaining support - despite widespread disappointment with the Labour government, one must be aware of the politics of certain wards and constituencies with a large population of South Asian origin. It is no secret that bloc voting, patronage politics and encouraging residents to vote according to family or kinship ties have long been endemic in certain areas, practices that traditionally benefited the Labour Party. 74\% of Muslim councillors interviewed for one piece of research conducted in the late 1990s acknowledged having 'attempted to invoke loyalties along kinship/caste/biraderi lines in their appeals to Muslims at the local level'. ${ }^{31}$ Outright vote rigging has also characterized, and marred, some electoral contests, especially in Birmingham where in 2004 it was revealed that illegal practices with postal votes were widespread. In April 2005, six Labour councillors were found guilty of fraud "that would disgrace a banana republic". ${ }^{32}$ The Respect Party, and George Galloway in particular, campaigned against vote-rigging through postal voting and called for an end to postal voting on demand. Salma Yaqoob launched a legal challenge against the Labour victory in the Birmingham Sparkbrook and Small Heath constituency in 2005 arguing that there had again been irregularities with postal voting. Respect's own electoral success has been closely tied to the percentage of electors who are Muslim. Sparkbrook ward in Birmingham, which until recently was entirely represented by Respect councillors, actually has the highest percentage of Muslim residents in the whole of the UK (59\%). Other wards where Respect have managed to elect more than one local councillor such as Shadwell in Tower Hamlets and Green Street West in Newham also have a high concentration of residents who identified themselves as Muslim in the 2001 census (52\% and 
47\% respectively). ${ }^{33}$ Those Respect candidates that have been elected have invariably also been Muslim despite the party also fielding non-Muslim candidates. This was in fact one of the reasons for the split with the SWP. Despite all the efforts put into electing Respect candidates by SWP activists, they could never seem to elect one of their own. ${ }^{34}$ After the split, senior figures in the SWP even accused Respect of 'Tammany Hall communalism'. 35

There can be no doubt that Respect's support came disproportionately from the Muslim community although it did not aim to base itself alone on these voters. Allegations that Respect merely appeals to the 'Muslim vote' are overly simplistic. They also ignore the fact that all the main parties engage in tactics designed to win over specific communities. This is merely the nature of ethnic politics in Britain, which in turn is a result of the voting system which makes ethnic minority communities kingmakers at election time. One critical study of Respect noted that 'a sizeable proportion of the party's activists, candidates and representatives appear to come from Asian or Muslim backgrounds'. ${ }^{36}$ Again, this is far from being unique to Respect. It has now become common for all parties to put forward Muslim candidates in areas with large numbers of Muslim voters and not just in local elections. In the 2010 general election, all three major parties put forward Muslim candidates in the constituencies of Birmingham Ladywood and Bethnal Green and Bow. It would appear, then, that all parties try to appeal to a Muslim electorate. One of the most interesting developments in recent years is the establishment of the Conservative Muslim Forum set up after the 2005 election in order to connect Muslim voters with the Tories. Since then, two Muslim MPs have been elected for the Conservatives (Rehman Chishti and Sajid Javid) thanks in part to the introduction by David Cameron of the so called 'A-list' of parliamentary candidates. Baroness Warsi was also named as Minister without Portfolio.

Persuading people to vote for Respect, Muslim or not, required investment in local community politics. The party worked particularly hard to gain the trust of female voters and put forward a number of female candidates, notably Salma Yaqoob. She has gained much praise for the work she has done for the residents of her ward in Birmingham and was unsurprisingly re-elected as a councillor in 2010 with $45 \%$ of the vote. As a Muslim woman, she often has had to fight against the conservatism of some in the local community, as she explained in an interview:

I've had death threats and criticism that I support gays - because I have a clear anti-discrimination position and there have been claims that it is haram [forbidden in Islam] to vote for women. People say to me, 'Have you no shame?' and they accuse me of immodesty and ask my husband why he lets me speak in public. It's still an uphill struggle. ${ }^{37}$

She was also criticised when the Respect Party chose a candidate who happened to be from the same biraderi as a standing Liberal Democrat councillor. Respect relied more on a youth vote that was often in opposition to traditional ethnic politics. Those Muslim councillors who were elected for Respect also tended to be younger, thereby contributing to breaking down the tradition of electing older 'community leaders' who had strong ties 'back home' in South Asia. Former Respect councillor Harun Miah explains the importance of the youth vote:

Because this time [2010 general election] all the candidates are Bengali, there will be a split in the community. However, younger voters are more likely to vote for the candidate they want rather than simply following the family or wider community. This has always played into the hands of Respect. ${ }^{38}$

The involvement of young people in the election campaign of 2005 was certainly crucial in helping George Galloway get elected and almost achieved the same result for Salma Yaqoob. ${ }^{39}$ By 2010 , many of those who had initially been mobilised as part of Youth Respect had become disillusioned and the party could no longer count on such a wide network to go out and canvass for votes.

Some observers have also cited Respect's ties to religious organisations and mosques as being crucial to its success, particularly after Galloway's 2005 victory in Bethnal Green and Bow. 
This is something which Respect activists have in fact never attempted to hide, as Abjol Miah explains:

\begin{abstract}
No politician in Tower Hamlets is going to avoid rubbing shoulders with the big mosque [East London Mosque]. Oona King did it; ministers come and do it - because when they want something they'll go to the right places. It's natural. If I'm a councillor standing for election, I'd want to make sure that my local church, my local TRA [tenants and residents association], the school governors and my local mosque are all on board with me. Of course I'm going to approach them and speak in their gatherings. I'm not going to exclude myself from that, they need our help and we need their votes! They're part and parcel of society and an important power broker - we have to recognise and accept that. The Labour Party recognises that and the Tories do too and they both utilise that to full effect...Respect as a party never officially approached the [East London] Mosque but their support was crucial for George's campaign. All the mosques helped George because he did the right thing, he went and visited them and talked to them. They gave him advice and he took their advice but Respect never went to these institutions [seeking an agreement]. We've never done that because of the internal criticism of being just focused on Muslims. ${ }^{40}$
\end{abstract}

More recently, in Tower Hamlets both Respect and the local Labour Party have been accused of being in the hands of Islamic Forum Europe (IFE), an organisation that has its headquarters at the East London Mosque. Abjol Miah himself was accused of being an IFE activist in The Daily Telegraph and the Dispatches documentary Britain's Islamic Republic that aired on Channel 4 in March 2010, something he has always vehemently denied. ${ }^{41}$ The extent of the influence of this organisation and other Islamic groups on local politics is difficult to ascertain. However, most keen political observers in areas such as Tower Hamlets are well aware that such religious organisations and their members are important local actors. The emergence of Respect and its ability to get candidates elected is simply proof of this. ${ }^{42}$

\title{
Any future for Respect?
}

After the disastrous election results of May 2010, many might have expected Respect to fold. These results certainly discouraged many activists and the party conference in November that year resembled a local PTA meeting such was the meagre attendance. One small cause for hope was the election of Lutfur Rahman as the first directly elected mayor of Tower Hamlets. Respect activists had been the driving force behind the petition to get a referendum on whether to have an elected mayor and also campaigned heavily for the yes vote which prevailed with $60.3 \%$. Respect leaders saw this as a major tactical victory by placing executive power in the hands of the elected mayor rather than the previous cabinet system which favoured the Labour Party. In the mayoral election itself, they had thrown their weight behind Rahman who had initially won the Labour Party selection contest by an overwhelming majority before being deselected by the National Executive Committee. ${ }^{43}$ George Galloway had even considered throwing his hat into the ring before Rahman eventually decided to stand as an Independent. He was subsequently elected with a landslide $52 \%$ of the vote and in the subsequent by-election in December 2010 for the council seat he had vacated, the Respect candidate Fozol Miah won back his place in the council chamber that he had lost in May. At the start of 2011, Respect was down but not completely out. Galloway set his sights on election as an MSP and started campaigning in Glasgow where he had been an MP from 1987 to 2005. He was seeking election as part of the regional list for the city which crucially employs a proportional voting system. This factor had led to the election of Scottish Socialist Party candidates to Holyrood in 1999 and 2003. South Glasgow is home to a large Muslim population of Pakistani origin, indeed the first ever Muslim MP in Britain was Mohammad Sarwar who vacated his Glasgow Central seat for his son Anas at the 2010 general election. Galloway hoped that if he could pick up votes from the Muslim community and supporters of the far left, including some of his previous supporters in the area, he would gain the $5 \%$ of the vote needed for election on the regional list. Galloway's campaign focused on an anti-cuts message and went under the banner of 
the Coalition Against the Cuts. In the end, Galloway's 6,972 votes amounted to a mere 3.3\%, well behind the Scottish Green Party candidate Patrick Harvie who picked up the last seat on the Glasgow list. On the very same list two new Muslim MSPs were elected, Humza Yousaf for the SNP and Hanzala Malik for Labour. The Birmingham City Council elections brought more misery for Respect as local councillor Mohammed Ishtiaq lost out to Labour, leaving the party with only two elected representatives in Birmingham. This was then reduced to one when in July 2011 Salma Yaqoob announced her decision to resign citing health problems

The future remains bleak for Respect. It is extremely unlikely that the party could ever hope to elect an MP again under the current voting system. Galloway's success in 2005 was only possible because of the importance of the anti-war protest vote during an election when Labour's overall victory was assured. Even then, he scraped through with the narrowest of margins. His inability to win a seat in the Scottish Parliament, a significantly easier task given the voting system, also indicates that his star is waning, even if one should never bet against him achieving another spectacular election victory in the future. A return to the fold of Labour seems unlikely given the comments he has made about some of his former parliamentary colleagues, but under the leadership of Ed Milliband this scenario is not entirely out of the question if Galloway were to tone down his rhetoric. Few would doubt Galloway's inner desire to return as a prodigal son to the party he had joined as a boy. During his campaign for Holyrood, the Dundonian repeatedly claimed that he was 'a Labour man' who stood for 'real Labour values.' Although some Respect figures have some sympathy for Ed Milliband after he admitted that the Iraq war was a mistake, this does not mean that they would necessarily join or re-join the Labour Party. Nevertheless, Respect members have actively joined Labour activists in organising demonstrations against the cuts in public services such as the 'March for the Alternative' on $26^{\text {th }}$ March 2011.

If Salma Yaqoob were to return to politics, there could also be a place for her amongst the ranks of Labour. Indeed, she was courted by all the major parties after narrowly losing out to Roger Godsiff in the general election of 2005 and admitted that she had been offered a safe seat by Labour in $2010 .{ }^{44}$ However, her stance on some issues may be seen by many as a potential liability. In February 2011 she and her fellow Respect councillors in Birmingham were criticised for refusing to join a standing ovation in the council chamber for a Royal Marine Commando who had received the George Cross for his actions in Afghanistan. Yaqoob would certainly be an outspoken MP and admitted that 'I couldn't speak like I do if I was in Labour' ${ }^{45}$ Nevertheless, she has developed a national profile following several combative appearances on BBC's Question Time and would certainly be an ideal spokeswoman if Labour were seeking to win back disillusioned left-wing voters who felt alienated by changes wrought by New Labour. She could also help to repair the damaged bonds between the party and Muslim voters even if the days when ethnic minority votes automatically went to Labour are long over.

Abjol Miah has taken over from Yaqoob as Respect Party National Chair and faces an unenviable task in trying to make the party relevant again. The stark realities facing him had already been acknowledged by Clive Searle, the National Secretary, after the electoral setbacks of May 2011:

It appears clear now, with the exception of Tower Hamlets with its peculiar local circumstances, that the electoral space that we have sought to occupy in recent years has been closing since the final few weeks of the 2010 General Election campaign. As voters were faced with a stark choice between Labour and Tory governments most working people - many of whom had spent the previous few years disillusioned with Blair and then Brown - returned to the Labour fold. With the ConDems in power, and viciously cutting essential public services, that process has continued - and is likely to accelerate as the cuts begin to bite. ${ }^{46}$

The party has had to accept that it has lost those voters whom it had initially prised away from Labour. Its major weakness has been the inability to implant itself nationwide with Respect branches effectively being restricted to London and Birmingham with tiny pockets of support in areas such as Bradford, Bristol and Greater Manchester. Financial constraints have hampered any 
prospect of further expansion and too much responsibility was also heaped on the shoulders of Galloway and Yaqoob, the only recognizable figures associated with the party which, in the minds of most, was indelibly linked with the anti-war movement. Compared to forays into electoral politics by other groupings of the radical left, Respect's achievements can be seen as remarkable. It changed the political landscape in Tower Hamlets, although it now has just two councillors in the borough and a lone representative on Birmingham city council. The party will now have to concentrate on rebuilding itself in these areas and work towards the next set of local elections. Even if Respect does not survive until then, it has proved to be an interesting experiment in local democracy by demonstrating that small parties can have some limited success in British politics if they implant themselves in local communities. Gaining national recognition is however a much more arduous task, even with the mercurial and 'indefatigable' George Galloway.

\section{The University of Edinburgh, Edinburgh, UK \\ t.peace@ed.ac.uk}

\footnotetext{
${ }^{1}$ This article was written during a postdoctoral fellowship at the Chaire de recherche en immigration, ethnicité et citoyenneté (CRIEC) and I thank Professor Micheline Labelle and Professor Rachad Antonius for hosting me and providing such a wonderful research environment in Montreal. I also wish to thank Dr Chris Hanretty and the two anonymous reviewers for their insightful comments and suggestions.

${ }^{2}$ The only exceptions are R. Briggs, 'Who's afraid of the Respect party?', Renewal, 15, 2007, 89-97 and A. Clark, K. Bottom and C. Copus, 'More Similar Than They'd Like to Admit? Ideology, Policy and Populism in the Trajectories of the British National Party and Respect', British Politics, 3(4), 2008, 511-534.

${ }^{3}$ C. Copus, A. Clark, H. Reynaert and K. Steyvers, 'Minor Party and Independent Politics beyond the Mainstream: Fluctuating Fortunes but a Permanent Presence', Parliamentary Affairs, 62(1), 2009, 4-18.

${ }^{4}$ The role of the MAB overshadowed the early work conducted by a group of Muslim professionals from London named Just Peace.

${ }^{5}$ Galloway was found guilty of four of the five charges of bringing the party into disrepute (notably encouraging British troops to refuse to obey orders in Iraq).

${ }^{6}$ G. Galloway, 'Why I will stand against New Labour', The Guardian, 30 October 2003

${ }^{7}$ M. Tempest, 'Monbiot quits Respect over threat to Greens', The Guardian, 17 February 2004.

${ }^{8}$ Respect election manifesto 'A manifesto for the European elections on June 10: A referendum on Blair'.

${ }^{9}$ See D. Aaronovitch, 'Same old guff with an added ingredient', The Guardian, 5 June 2004 and S. Coates, 'Galloway group has air of familiarity, The Times, 9 June 2004.

${ }^{10}$ In 1999 the Green Party elected an MEP in London with 87,545 votes but in 2004 the threshold was 115, 000. For a more detailed analysis of Respect's performance see G. Borisyuk, C. Rallings, M. Thrasher and H. van der Kolk, 'Voter support for minor parties: Assessing the Social and Political Context of Voting at the 2004 European Elections in Greater London', Party Politics, 13(6), 2007, 669-693.

${ }^{11}$ Parties must win at least $5 \%$ of the party list vote in order to win any seats in the London Assembly.

12 This was not Respect's first elected representative as Galloway was still MP for Glasgow Kelvin and sitting councillors in Nuneaton and Preston had joined Respect.

${ }^{13}$ The exception was the late Tony Banks (West Ham) who was one of the Labour rebels who voted in favour of the backbench amendment that the case for war with Iraq was "unproven". He did not contest his seat in 2005.

${ }^{14} \mathrm{P}$. Barkham, 'MP accuses Galloway backers of anti-semitism' The Guardian, 12 April 2005.

${ }^{15}$ P. Webb, 'The Continuing Advance of the Minor Parties', Parliamentary Affairs, 58(4), 2005, 757-775

16 The transcript and video of this interview is available at

http://news.bbc.co.uk/2/hi/uk_news/politics/vote_2005/blog/4519553.stm

${ }^{17}$ His decision to participate drew much derision in the media but also serious political criticism for wasting his time on television instead of working for his constituents. W. Pavia, 'Where's our MP? Constituents say Galloway should get back to work', The Times, 9 January 2006.

${ }^{18}$ In the Newham mayoral contest Akhtar Jafar came in second behind the incumbent Robin Wales.

${ }^{19}$ Keith was defeated in 2006 by Abjol Miah who had attended his lectures at Goldsmiths university. Keith again failed in his bid for re-election at the 2010 local elections in Tower Hamlets.

${ }^{20}$ The rebel councillors initially set up a new political group called Respect (Independent). Oliur Rahman, Rania Khan and Lufta Begum eventually defected to Labour in 2008 and since 2010 have again become independents. The other rebel Ahmed Hussain eventually joined the Conservatives.
} 
${ }^{21}$ Interestingly, the original party website http://www.respectcoalition.org had always been controlled by party members who were affiliated with the SWP and so this then linked to the alternative party they set up - The Left Alternative. The Galloway faction was initially forced to create a new website http://www.respectrenewal.org although the official website of the party is now http://www.voterespect.org/

${ }^{22}$ A. Smith 'Respect off conference agenda as Galloway's party splits in two', The Independent, 9 November 2007.

${ }^{23}$ Respect decided to endorse eventual runner up Ken Livingstone.

24 'Selly Oak MP Lynne Jones 'not happy' over candidate' 9 April 2010

http://news.bbc.co.uk/2/hi/uk_news/politics/election_2010/england/8611719.stm

${ }^{25}$ Studies have shown that the party polled best in areas containing large Muslim populations, see Borisyuk et al.

${ }^{26}$ According to the report of the Electoral Commission Election 2005: campaign spending, Respect spent $£ 320,716$ almost half of which was used on unsolicited material to electors.

${ }^{27}$ For example, in January 2009 the party had to forfeit a donation of $£ 4,824.21$ from a benefactor who was later found to be not registered on a UK electoral register at the time of the donation in June 2007.

${ }^{28}$ O. Saeed, 'Labour has forfeited the Muslim vote', The Guardian, 25 May 2004.

${ }^{29}$ Local election flyer 'George Galloway - Fighting for Muslim rights!' used during the 2004 European parliament campaign.

30 The IPB was set up after the Rushdie affair in 1989, it never managed to retain its deposit in any of the elections it contested, see P. Lewis, Islamic Britain : religion, politics, and identity among British Muslims, I.B. Tauris, 1994. Former executive member and home affairs spokesman for the IPB, Mohammad Naseem, actually stood as a candidate for Respect in Birmingham Perry Barr at the 2005 General Election challenging the sitting Muslim Labour Party candidate Khalid Mahmood. Naseem was also a key funder for Respect in its early years. Candidates for the Muslim Party contested the 2001 general election in four Birmingham constituencies averaging $1 \%$ of the vote. The only political party of an explicitly Islamic nature that is currently registered with the Electoral Commission is the Islam Zinda Baad Platform which stood one candidate in Rochdale in 2005 and 2010 receiving respectively $0.9 \%$ and $1.2 \%$ of the vote.

${ }^{31}$ K. Purdam, 'Democracy in Practice: Muslims and the Labour Party at the Local Level', Politics, 21(3), 2001, 147-

157. The term biraderi is generally translated as extended family, for a discussion see M. Bolognani, Crime and Muslim Britain: Race, Culture and the Politics of Criminology Among British Pakistanis, I.B. Tauris, 2009, p.57-62.

32 J. Stewart, 'A Banana Republic? The Investigation into Electoral Fraud by the Birmingham Election Court', Parliamentary Affairs, 59(4), 2006, 654-667. Galloway also accused Labour of committing electoral fraud in Bethnal Green and Bow.

33 These statistics can be viewed at http://neighbourhood.statistics.gov.uk. Interestingly, Respect received $47 \%$ of the vote in the ward of Green Street West for the European Elections in 2004, see Borisyuk et al.

${ }^{34}$ The one exception to this is Michael Lavalette a lecturer in social policy at the University of Liverpool who became a local councillor in Preston in 2003 for the Socialist Alliance before becoming part of Respect. He was re-elected in 2007 as a Respect councillor but lost his seat in May 2011 when he represented the Trade Unionist and Socialist Coalition.

${ }^{35}$ C.Harman, 'The crisis in Respect', 18 December 2007. http://www.isj.org.uk/?id=396

${ }^{36}$ Clark et al, op.cit, p.518

${ }^{37}$ M. Bunting, 'Respect candidate spearheads quiet revolution to get Muslim women involved in politics', The Guardian, 23 April 2010

${ }^{38}$ Harun Miah interview

${ }^{39}$ T. O'Toole and R. Gale, 'Contemporary grammars of political action among ethnic minority young activists', Ethnic and Racial Studies, 33(1), 2010, 126-143.

${ }^{40}$ Abjol Miah interview

${ }^{41}$ Abjol Miah subsequently sought recourse from the Press Complaints Commission which concluded that The Daily Telegraph had breached clause 1 (accuracy) of the Editors' Code.

${ }^{42}$ As Dave Hill remarked regarding the election of Mayor Rahman: "The world and its Uncle Bert know that politicised forms of Islamic activism are an established part of the territory in Tower Hamlets - without them Respect could not have existed - and those involved don't seek to deny it"

http://www.guardian.co.uk/society/davehillblog/2011/feb/11/lutfur-rahman-labour-tower-hamlets

${ }^{43}$ Rahman's deselection was partially a result of the allegations in the Dispatches documentary which also linked him to the IFE. See G. Eaton, 'A bad night for Labour in Tower Hamlets' 22 October 2010

http://www.newstatesman.com/blogs/the-staggers/2010/10/labour-rahman-respect-beaten

44 'Respect leader Salma Yaqoob to stand down as Birmingham councillor', Birmingham Post, 7 July 2011

${ }^{45}$ Bunting, op.cit

${ }^{46}$ C. Searle 'After the Election - where now for Respect?', 22 May 2011. http://www.voterespect.org/2011/05/afterelection-where-now-for-respect.html 